\title{
CXCL12 Regulates the Cholinergic Locus and CHT1 Through Akt Signaling Pathway
}

\author{
Jing Yan Wenhui Zhao $^{\mathrm{a}}$ Meixia Guo ${ }^{\mathrm{b}} \quad$ Xuefei Han ${ }^{\mathrm{b}}$ Zhiwei Feng \\ aXinxiang medical university, Xinxiang, bepartment of Physiology, University of Zhengzhou, \\ Zhengzhou, China
}

\section{Key Words}

Acetylcholine $\cdot$ Choline acetyltransferase $•$ GSK690693 • Akt • CXCL12

\begin{abstract}
Background: CXCL12 is pivotal for cholinergic neurons, and it induces the expressions of several genes that are essential for synthesis and storage of acetylcholine(ACh), specifically choline acetyltransferase, vesicular ACh transporter (VAChT), and choline transporter. The present study explored the impact of pharmacological Akt inhibition upon cholinergic gene expression. Methods: Western blotting was employed to determine the level of $p-A K T, R T-$ PCR to check the mRNA levels of and CHT1(choline transporter1),VAChT and ChAT, ELISA to decipher the secretion of ACh and the activity of choline acetyltransferase. Results: Here we demonstrated, in the rat pheochromocytoma cell line PC12 and in primary rat neuronal cultures, that CXCL12-evoked up-regulation of CHT1, VAChT and ChAT was mediated by Akt. Inhibition of Akt by the pharmacological inhibitor GSK690693 eliminated CXCL12stimulated increases in cholinergic gene expression. Moreover, treatment with GSK690693 reversed CXCL12-evoked increases in choline acetyltransferase activity and ACh production. Conclusion: Our results suggest that CXCL12 contributes to cholinergic gene expression via Akt signaling pathway.

\section{Introduction}

CXCL12(also known as stromal cell-derived factor 1) binds to C-X-C chemokine receptor 4 (CXCR4), thereby activating various downstream signaling cascades including Akt/ PKB [1-3]. CXCL12 guides cell migration during embryogenesis, immune cell trafficking, cancer metastasis as well as pathological pain[4-7]. In the nervous system, CXCL12 is crucial for neuronal guidance in developing brain, intercellular communication and the neuropathogenesis of acquired immunodeficiency syndrome[8]. Moreover, CXCL12 is 
constitutively expressed in cholinergic neurons in the medial septum[8, 9] and functionally involved in the neuron migration, the synaptic formation[10] and neurotransmitters release $[11,12]$. As a strong chemoattractant for T- and B-lymphocytes as well as inflammatory monocytes, CXCL12 is regarded as a mediator of pathogenic inflammation in the CNS $[13,14]$. The inflammation observed in the central nervous system(CNS) of multiple sclerosis(MS) patients and of mice with experimental autoimmune encephalomyelitis(EAE) is associated with enhanced expression of CXCL12 $[15,16]$.

We have been studying the intracellular signaling pathways that mediate these biological actions of CXCL12. CXCL12 stimulates Akt and this pathway is important for cholinergic function [3,17-19]. Upon activation, Akt phosphorylates numerous downstream targets, thereby participating in the regulation of cell survival and cell cycle progression[20]. Phosphorylation of various neuronal targets allows Akt to control different neuronal functions, e.g. GABA receptor stabilization and memory consolidation[21, 22].

The cholinergic system is based on the neurotransmitter acetylcholine (ACh) and found widely distributed in both central and peripheral nervous systems. ACh plays a pivotal role in learning and memory performance, dysfunction of the AChergic synapse is the major cause of the Alzheimer's disease[23, 24]. ACh, synthesized by the enzyme Choline acetyltransferase (ChAT) which catalyses the acetylation of choline with acetyl-CoA, is accumulated in synaptic vesicles through a vesicular acetylcholine transporter (VAChT) driven by the transvesicular proton gradient linked to an ATPase enzyme[25]. ACh present at the synaptic cleft is promptly hydrolyzed by the enzyme acetylcholinesterase (AChE), forming acetate and choline, which is recycled into the presynaptic nerve terminal by the high-affinity choline transporter (CHT1). Uptake of choline by CHT1 is the rate-limiting step for synthesis of acetylcholine. Nothing is known, however, on the putative participation of CXCL12/CXCR4/PI3K in the regulation of ACh.

The present study was undertaken to explore the role of AKT in cholinergic gene expression in the pheochromocytoma cell line pheochromocytoma 12(PC12) cells and in primary septal neurons. Here we demonstrate that inhibition of Akt blunts CXCL12-induced cholinergic-specific mRNA level and protein abundance as well as ACh production. We suggest that Akt plays a pivotal role in the cholinergic gene expression evoked by CXCL12.

\section{Materials and Methods}

\section{Ethics Statement}

All procedures and assays were approved by the Institutional Animal Care and Use Committee of Xinxiang medical University.

\section{Cell culture and treatments}

Experiments were performed in Pheochromocytoma(PC12) cells cultured in DMEM containing 10\% fetal calf serum and 1\% antibiotic/antimycotic solution.

Primary septal cultures were prepared from the newborn Sprague-Dawley (SD) rats (provided by laboratory animal center in henan province license SCXK 2010-0002) as described previously [26]. Briefly, collected neurons were seeded in a concentration of $1 \times 10^{6}$ cells $/ \mathrm{cm}^{2}$. Cells were cultured for $6 \mathrm{~d}$ in medium, consisting of Eagle's minimum essential medium containing $10 \mathrm{~mm}$ sodium bicarbonate, 1\% glucose, 1 $\mathrm{mm}$ l-glutamine, $20 \mathrm{~mm} \mathrm{KCl}, 1 \mathrm{~mm}$ sodium pyruvate, and 10\% (v/v) heat-inactivated fetal bovine serum (Sigma). After $24 \mathrm{~h}$ in culture, the culture medium was replaced with Neurobasal medium containing B27 supplements (Invitrogen) in a humidified atmosphere $\left(6 \% \mathrm{CO}_{2}, 94 \%\right.$ room air $)$ at $37{ }^{\circ} \mathrm{C}$. Approximately $12 \mathrm{~h}$ later, $5 \mu \mathrm{M}$ cytosine arabinoside was added to the dishes to prevent the growth of non-neuronal cells. Cell treatments with the Akt inhibitor GSK690693 were started 12h later. GSK690693 is a small molecule ATP-competitive inhibitor of the pro-survival kinase Akt, is a pan-Akt kinase inhibitor, has been preclinically tested in osteosarcoma and ALL xenografts and is now in phase I of clinical trials in sarcomas, neuroblastoma, non-glioblastoma brain tumors and lymphoma [27]. The cells were pre-treated with 1 $\mu \mathrm{M}$ GSK690693 or 10 $\mu \mathrm{M}$ HIMO for $12 \mathrm{~h}$, before addition of $300 \mathrm{ng} / \mathrm{mL}$ CXCL12.

\section{KARGER}




\section{Cellular Physiology Cell Physiol Biochem 2016;40:982-992 \begin{tabular}{ll|l} 
DOI: 10.1159/000453155 & $\begin{array}{l}\text { O 2016 The Author(s). Published by S. Karger AG, Basel } \\
\text { www.karger.com/cpb }\end{array}$
\end{tabular} \\ Yan et al.: CXCL12 Regulates Cholinergic Locus via Akt}

Cell viability assay

To check the neurotoxic effect of GSK690693, cells were treated with GSK690693 in different concentrations. Each group of cells were seeded in 96-well microtiter plates and incubated for 24 hours. At different points, the 3-(4,5-dimethylthiazol-2-yl)-2,5-diphenyltetrazolium bromide (MTT) assay was performed by adding $20 \mu \mathrm{L}$ of MTT ( $5 \mathrm{mg} / \mathrm{mL}$, Sigma, USA) for $4 \mathrm{~h}$. Finally, Light absorbance of the solution was measured at $570 \mathrm{~nm}$ on a microplate reader (Perkin- Elmer, USA) to determine the percentage of viable cells and account for cell death induced according to the outlined equation below:

$\%$ Cell viability $=100^{*}$ (Absorbance of treated cells-Absorbance of blank)/(Absorbance of untreated cells-Absorbance of blank)

\%Cell death $=100 \%$ - \%Cell viability

\section{Western blotting}

Protein abundance was determined. The cells were washed in ice-cold PBS. RIPA lysis buffer(Cell Signaling, United states) containing phosphatase and protease inhibitor cocktail tablet(Thermo Fisher Scientific, United States) was added to the washed cells. The samples were incubated on ice for $30 \mathrm{~min}$ and then centrifuged at $14,000 \mathrm{rpm}$ and $4^{\circ} \mathrm{C}$ for $20 \mathrm{~min}$. The supernatant was removed and used for Western blotting. Total protein (40-60 $\mu \mathrm{g}$ ) was separated by SDS-PAGE, thereafter transferred to PVDF membranes and blocked in 5\% non-fat milk/Tris-buffered saline/Tween-20 (TBST, PH 7.4) at room temperature for 1 hour. Membranes were probed overnight at $4^{\circ} \mathrm{C}$ with different primary antibodies in PBST containing $1 \% \mathrm{BSA}$ at $4^{\circ} \mathrm{C}$. The primary antibodies included the following: anti-rabbit P-AktSer473(Sigma, United States, 1:1500), total-Akt(Sigma, United States, 1:1000), total-GSK3(Sigma, United States, 1:1000) as well as pGSK-3 3 Ser9(Sigma, United States, 1:1500). After incubation with horseradish peroxidase-conjugated antirabbit secondary antibody (Sigma, United States, 1:1000) for 2 hour at room temperature, the bands were visualized with enhanced chemiluminescence reagents (Sigma, United States). Densitometric analysis was performed using quantity One software.

\section{Quantative Real Time-PCR (qRT-PCR)}

Total RNA was extracted from PC12 cells and primary septual cultures in TriFast (Peqlab, United States) according to the manufacturer's instructions. After DNAse digestion reverse transcription of total RNA was performed using Transcriptor High Fidelity cDNA Synthesis Kit (Roche Diagnostics, United States). Real-time polymerase chain reaction (RT-PCR) of the respective genes were set up in a total volume of $20 \mu \mathrm{l}$ using $40 \mathrm{ng}$ of cDNA, $500 \mathrm{nM}$ forward and reverse primer and 2x GoTaq ${ }^{\circledR}$ qPCR Master Mix (Promega, United States) according to the manufacturer's protocol. Cycling conditions were as follows: initial denaturation at $95^{\circ} \mathrm{C}$ for $2 \mathrm{~min}$, followed by 40 cycles of $95^{\circ} \mathrm{C}$ for $15 \mathrm{sec}, 58^{\circ} \mathrm{C}$ for $15 \mathrm{sec}$ and $68^{\circ} \mathrm{C}$ for $20 \mathrm{sec}$. For amplification the following primers were used $\left(5^{`}>3^{`}\right.$ orientation): The following primers were used:

GAPDH (TATA box-binding protein):

forward (5'-3'): CGGAGTCAACGGATTTGGTCGTAT

reverse (5'-3'): AGCCTTCTCCATGGTGGTGAAGAC

VACHT

forward (5'-3'): AGCGGGCCTTTCATTGATCG

reverse (5'-3'): GGCGCACGTCCACCAGAAAGG

CHT1

forward ( 5 '-3'): CGGGGAACCATTGAATTCGTTGAAGTCTAC

reverse (5'-3'): GGGGCAAGCTTCCACTTTCAAATAGATACT

ChAT

forward (5'-3'): CGGGATCCTGCCTCATCTCTGGTGT

reverse (5'-3'): GGCGGAATTCAATCACAACATC

Specificity of PCR products was confirmed by analysis of a melting curve. Real-time PCR amplifications were performed on a CFX96 Real-Time System (Bio-Rad, United States) and all experiments were done in duplicate. GAPDH was amplified to standardize the amount of sample RNA. Relative quantification of gene expression was achieved using the $\Delta \mathrm{CT}$ method as described[28]. 


\section{Cellular Physiology Cell Physiol Biochem 2016;40:982-992 \begin{tabular}{l|l} 
and Biochemistry & DOI: 10.1159/000453155 \\
(c) 2016 The Author(s). Published by S. Karger AG, Basel
\end{tabular} \\ Yan et al.: CXCL12 Regulates Cholinergic Locus via Akt}

ELISA

ELISA assay was applied to detect the ACh release in cell culture medium and ChAT in cells. For ACh release detection, $5 \times 10^{5}$ cells were seeded in 6-well plates with $2 \mathrm{ml}$ medium, after $24 \mathrm{~h}$ the culture medium were collected. $10 \mathrm{ul}$ culture medium was added into ACh ELISA Kit (Lengton, Shanghai, China) according to the manufacturer's instructions. As for ChAT measurement, cells were lysed and collected by centrifugation. $100 \mu \mathrm{L}$ samples was then added into ChAT ELISA kit(Antibodies, United States) according to the manufacturer's instructions.The spectrophotometry of panels were read at $450 \mathrm{~nm}$ and calculated according to the standard curve.

\section{Statistics}

Data are provided as means \pm SEM, $n$ represents the number of independent experiments. All data were tested for significance using one-way ANOVA followed by post hoc Bonferroni test was applied when multiple comparisons between different groups were made. Only results with $\mathrm{p}<0.05$ were considered statistically significant.

\section{Results}

CXCR4 antagonist AMD3100 abolishes the CXCL12-evoked phosphorylation of Akt and GSK-3

In order to understand the mechanism of action of CXCL12, antagonist AMD3100 was utilized. PC12 cells were treated with $5 \mu \mathrm{g} / \mathrm{mL}$ AMD3100 for $12 \mathrm{~h}$, then stimulated with 300 $\mathrm{ng} / \mathrm{mL}$ CXCL12 for $30 \mathrm{~min}$. Western blotting was used to check the phosphorylation of Akt and its downstream effector glucose synthase kinase-3(GSK-3). As illustrated in Fig.1, AMD3100 significantly decreased the phosphorylation of Akt and GSK-3 in response to CXCL12(Fig. 1). Thus, CXCL12 induces the phosphorylation of Akt and GSK-3 through CXCR4.

Akt inhibitor GSK690693(1 $\mu$ M) does not change the viability of cells

Akt, a downstream effector of the PI3K pathway, is associated with transmission of PI3K survival signals. Therefore, the viability of the treated cells was concerned. we used GSK690693, an affective Akt inhibitor to treat PC12 cells in 500nM, $1 \mu \mathrm{M}$ and $1.5 \mu \mathrm{M}$, respectively. As illustrated in Fig. 2, exposure of cells to GSK690693 in $1.5 \mu \mathrm{M}$ for 12 hours leaded to a significant decrease of the cell viability. However, cell viability decreased by 15$25 \%$ following $12 \mathrm{~h}$ of exposure of $1 \mathrm{uM}$ of GSK69069031. Thus, $1 \mu \mathrm{M}$ GSK690693 was utilized to perform the experiments.

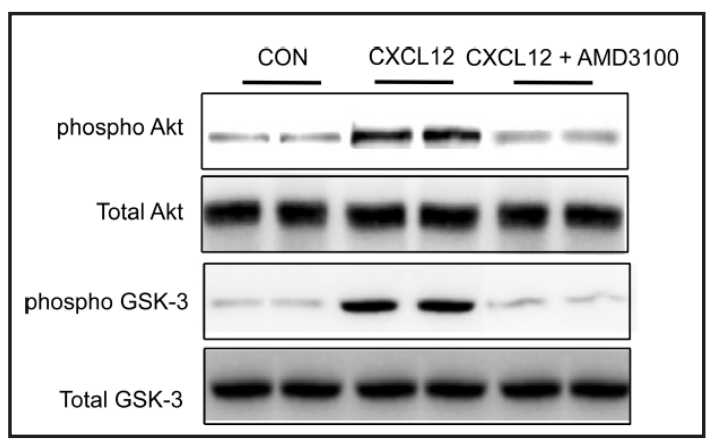

Fig. 1. Effect of the CXCR4 antagonist AMD3100 on protein phosphorylation. Original Western blot showing the protein abundance of p-GSK3 and p-AKT in PC12 cells without or with a prior $30 \mathrm{~min}$ treatment with $300 \mathrm{ng} / \mathrm{ml} \mathrm{CXCL12} \mathrm{in} \mathrm{the} \mathrm{absence} \mathrm{and} \mathrm{presence}$ of $\operatorname{AMD} 3100(1 \mu \mathrm{M})$.

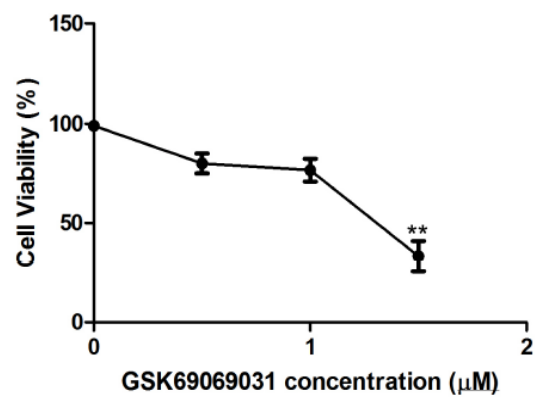

Fig. 2. Effect of the Akt inhibitor GSK690693 on PC12 cells viability. MTT analyse was used to determine cell death. PC12 cells were incubated with CXCL12(300 ng/ml) without or with the treatment of GSK690693(0.5, 1, $1.5 \mu \mathrm{M})$ for 24h. Data are means \pm SEM ( $\mathrm{n}=5$ independent experiments). ${ }^{* *}$ $(\mathrm{p}<0.01)$ indicates significant difference from control (ANOVA). 
Fig. 3. Effect of the Akt inhibitor GSK690693 on protein phosphorylation. Original Western blot showing the protein abundance of AKT and p-AKT in PC12 cells without or with a prior $30 \mathrm{~min}$ treatment with $300 \mathrm{ng} /$ $\mathrm{ml} \mathrm{CXCL12}$ in the absence and presence of GSK690693(1 $\mu \mathrm{M})$.
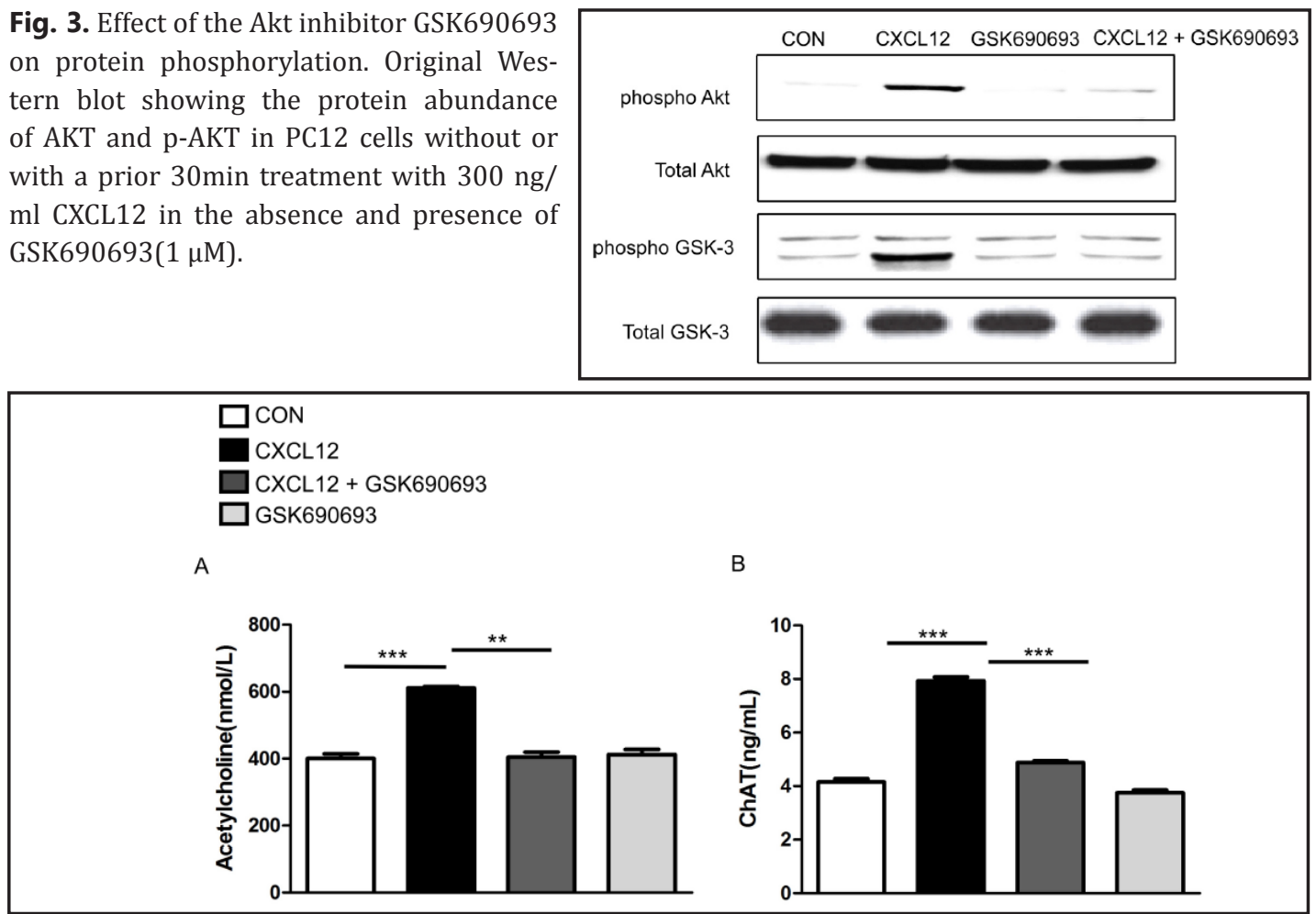

Fig. 4. Effect of the Akt inhibitor GSK690693 on ChAT activity and ACh production. A. Arithmetic means \pm SEM ( $n=4$ independent experiments) of ACh concentration in PC12 without (white bar) or with a prior 30min treatment with $300 \mathrm{ng} / \mathrm{ml}$ CXCL12 in the absence (black bar) and presence (grey bar) of GSK690693(1 $\mu$ M). B. Arithmetic means \pm SEM ( $n=4$ independent experiments) of ChAT activity in PC12 without (white bar) or with a prior 30min treatment with $300 \mathrm{ng} / \mathrm{ml} \mathrm{CXCL12} \mathrm{in} \mathrm{the} \mathrm{absence} \mathrm{(black} \mathrm{bar)} \mathrm{and}$ presence (grey bar) of GSK690693 $(1 \mu \mathrm{M})$. ${ }^{* *}(\mathrm{p}<0.01)$, *** $(\mathrm{p}<0.001)$ indicates significant difference from control (ANOVA).

Akt inhibitors abolish the CXCL12 effects upon ChAT activity and ACh production

In order to explore the involvement of Akt in cholinergic function, PC12 cells were pretreated with GSK690693(1 $\mu \mathrm{M})$ for $12 \mathrm{~h}$, then stimulated with $300 \mathrm{ng} / \mathrm{mL}$ CXCL12 for $30 \mathrm{~min}$. The inhibition of Akt activity was demonstrated by western blotting with phosphor-specific antibodies against Akt and GSK-3. As illustrated in Fig. 3, GSK690693 significantly decreased the phosphorylation of Akt and GSK-3 in response to CXCL12(Fig. 3).

In order to explore whether CXCL12-stimulated ACh production was affected in the presence of Akt inhibitors, the cells were treated with GSK690693 or HIMO $(10 \mu \mathrm{M})$ in the presence of CXCL12 for 12h. HIMO(1L-6-hydroxymethyl-chiro-inositol 2(R)-2-O-methyl3-O-octadecylcarbonate), a 3'-modified phosphatidylinositol analogue shown to be an effective Akt inhibitor, has a marked preference for Akt $\left(\mathrm{IC}_{50}\right.$ of $\left.5 \mu \mathrm{M}\right)$ over PI3K( $\mathrm{IC}_{50}$ of 83 $\mu \mathrm{M})[29,30]$. As illustrated in Fig. 4 and 5, CXCL12 increased ChAT activity and ACh release significantly(Fig. 4A and B, Fig. 5A and B). Pre-treatment with these inhibitors completely abolished these increases. However, treatment with these inhibitors alone did not affect ACh release and ChAT activity. Moreover, exposure of CXCL12-pretreated cells to GSK690693 or HIMO did not modify ChAT activity and ACh contents. Thus, inhibition of Akt prevents CXCL12 from up-regulation of ACh production in PC12 Cells.

Akt inhibitors prevent CXCL12-mediated up-regulation of cholinergic mRNA expression

In order to shed light on the role of Akt inhibition in the mRNA expression of ChAT and VAChT as well as CHT1, RT-PCR was employed. As illustrated in Fig. 6 and Fig. 7, CXCL12 


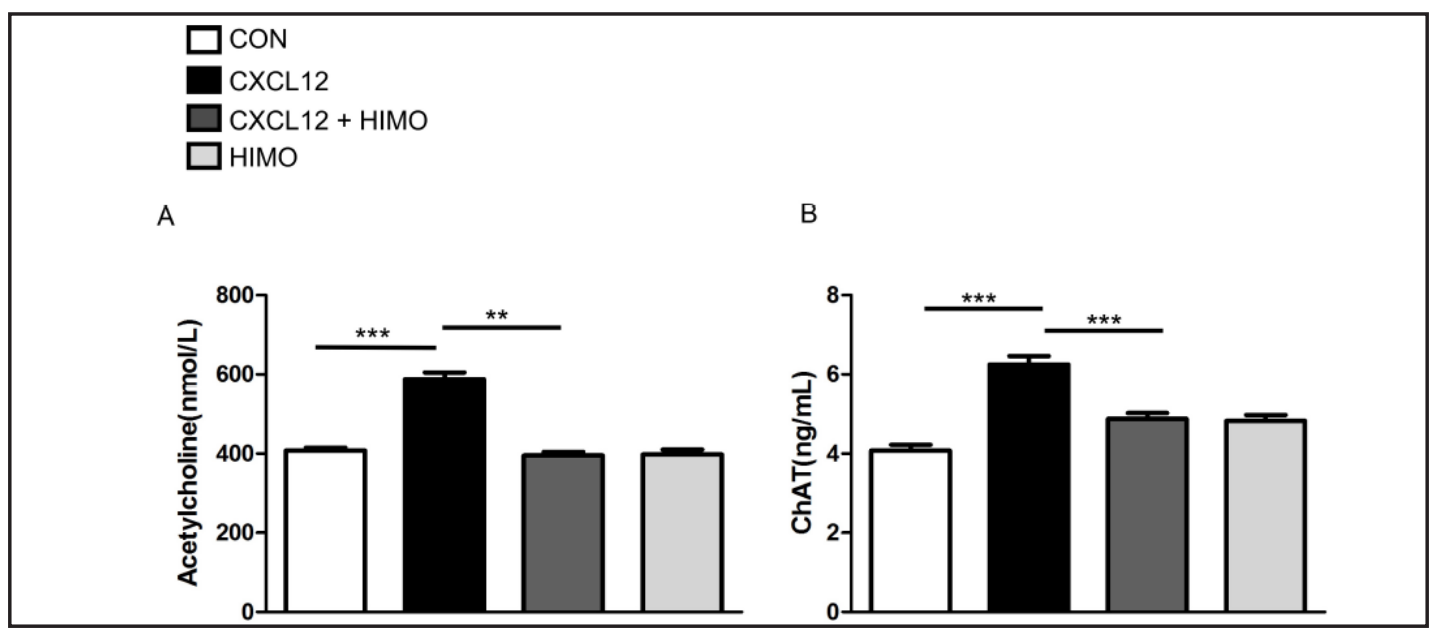

Fig. 5. Effect of the Akt inhibitor HIMO on ChAT activity and ACh production. A. Arithmetic means \pm SEM ( $n=4$ independent experiments) of ACh concentration in PC12 without (white bar) or with a prior 30min treatment with $300 \mathrm{ng} / \mathrm{ml} \mathrm{CXCL12}$ in the absence (black bar) and presence (grey bar) of $\operatorname{HIMO}(10 \mu \mathrm{M})$. B. Arithmetic means \pm SEM ( $\mathrm{n}=4$ independent experiments) of ChAT activity in PC12 without (white bar) or with a prior $30 \mathrm{~min}$ treatment with $300 \mathrm{ng} / \mathrm{ml} \mathrm{CXCL12}$ in the absence (black bar) and presence (grey bar) of HIMO $(10 \mu \mathrm{M}){ }^{* *}(\mathrm{p}<0.01),{ }^{* * *}(\mathrm{p}<0.001)$ indicates significant difference from control (ANOVA).

Fig. 6. Akt inhibitor GSK690693 eliminates CXCL12-induced increases in cholinergic mRNA accumulation. A. Arithmetic means \pm SEM $(\mathrm{n}=6$ independent experiments) of VAChT transcriptional level in untreated(white bar) and CXCL12 treated(black bar) PC12 cells in the presence (grey bar) of GSK690693(1 $\mu \mathrm{M})$. B. Arithmetic means \pm SEM $(n=5$ independent experiments) of ChAT transcriptional level in

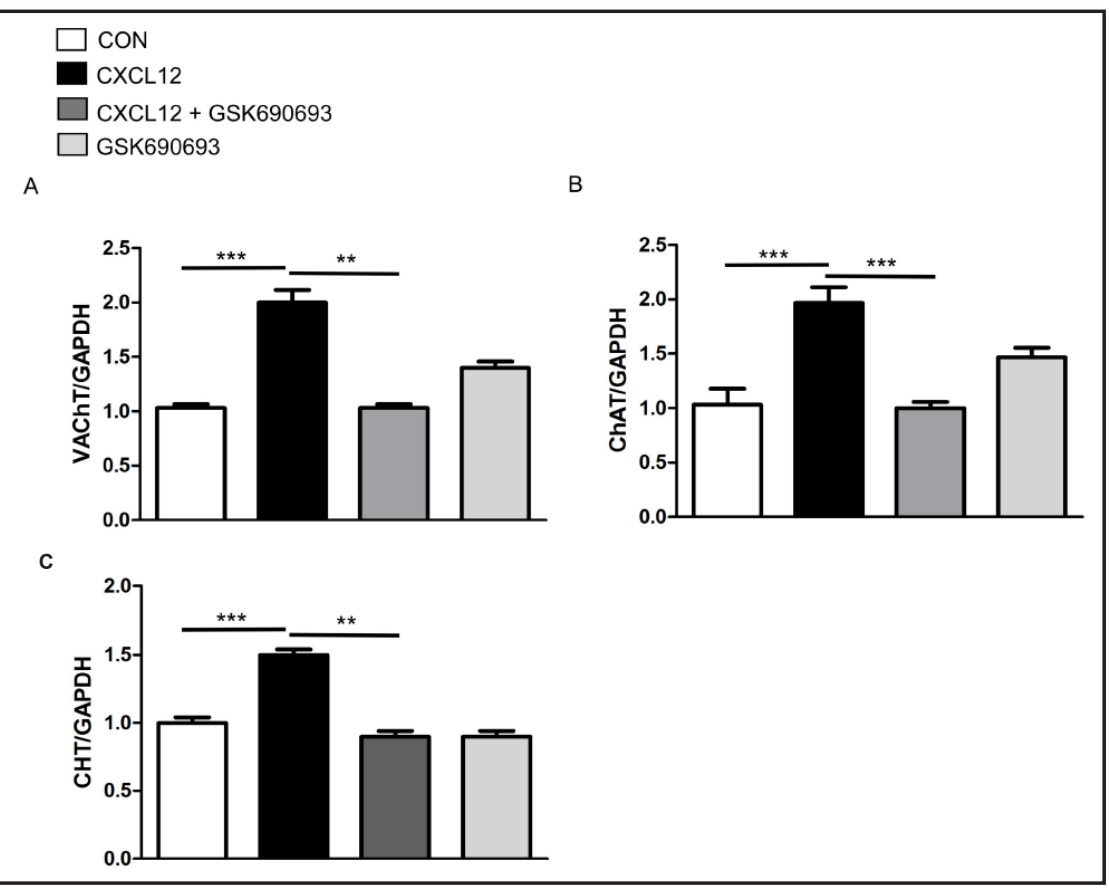
untreated(white bar) and CXCL12 treated(black bar) PC12 cells in the presence (grey bar) of GSK690693(1 $\mu \mathrm{M})$. C. Arithmetic means \pm SEM ( $\mathrm{n}=5$ independent experiments) of CHT1 transcriptional level in untreate$\mathrm{d}$ (white bar) and CXCL12 treated(black bar) PC12 cells in the presence (grey bar) of GSK690693(1 $\mu \mathrm{M}) .{ }^{* *}$ $(\mathrm{p}<0.01),{ }^{* * *}(\mathrm{p}<0.001)$ indicates significant difference from control (ANOVA).

increased both ChAT and VAChT as well as CHT1 mRNA expressional levels in PC12 cells. In contrast, in the presence of GSK690693 and HIMO, CXCL12-induced increases in these three genes were blunted. Moreover, in the absence of CXCL12, GSK690693/HIMO treatment did not affect basal ChAT and VAChT mRNA levels. So we conclude that inhibition of Akt eliminates CXCL12-induced up-regulation of ChAT and VAChT as well as CHT1 mRNA levels in PC12 cells. 
Fig. 7. Akt inhibitor HIMO eliminates CXCL12-induced increases in cholinergic mRNA accumulation. A. Arithmetic means \pm SEM (n $=6$ independent experiments) of VAChT transcriptional level in untreated(white bar) and CXCL12 treated(black bar) PC12 cells in the presence (grey bar) of $\operatorname{HIMO}(10 \mu \mathrm{M})$. B. Arithmetic means \pm SEM (n $=5$ independent experiments) of ChAT transcriptional level in untreated(white bar) and CXCL12 treated(black

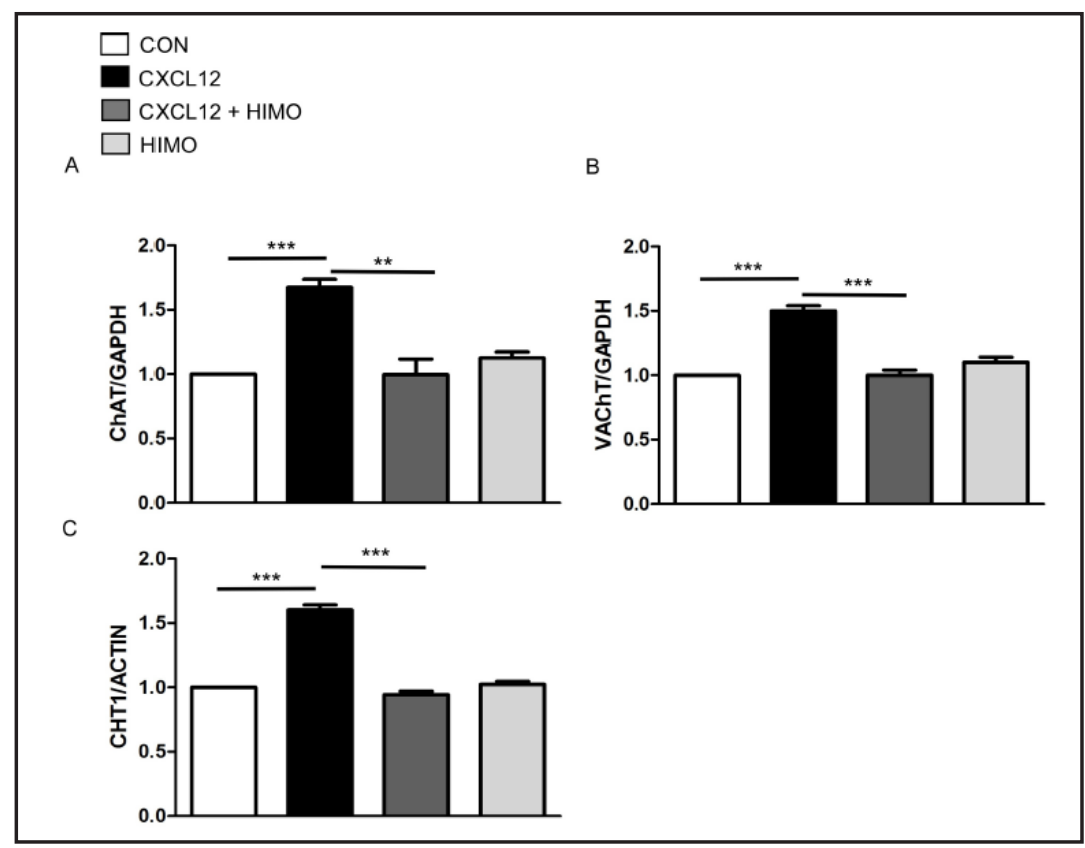
bar) PC12 cells in the presence (grey bar) of HIMO $(10 \mu \mathrm{M})$. C. Arithmetic means \pm SEM ( $n=5$ independent experiments) of CHT1 transcriptional level in untreated(white bar) and CXCL12 treated(black bar) PC12 cells in the presence (grey bar) of $\operatorname{HIMO}(10 \mu \mathrm{M}){ }^{* *}(\mathrm{p}<0.01),{ }^{* * *}(\mathrm{p}<0.001)$ indicates significant difference from control (ANOVA).

Fig. 8. Akt inhibitor blunts CXCL12-evoked cholinergic gene expression in primary septal neurons. A. Arithmetic means \pm SEM ( $\mathrm{n}=6$ independent experiments) of ChAT transcriptional level in untreated(white bar) and CXCL12 treated(black bar) septal neurons in the presence (grey bar) of GSK690693(1 $\mu \mathrm{M})$. B. Arithmetic means \pm SEM ( $\mathrm{n}=5$ independent experiments) of VAChT transcriptional level in untreated(white bar) and CXCL12 treated(black bar) neurons in the presence (grey bar)

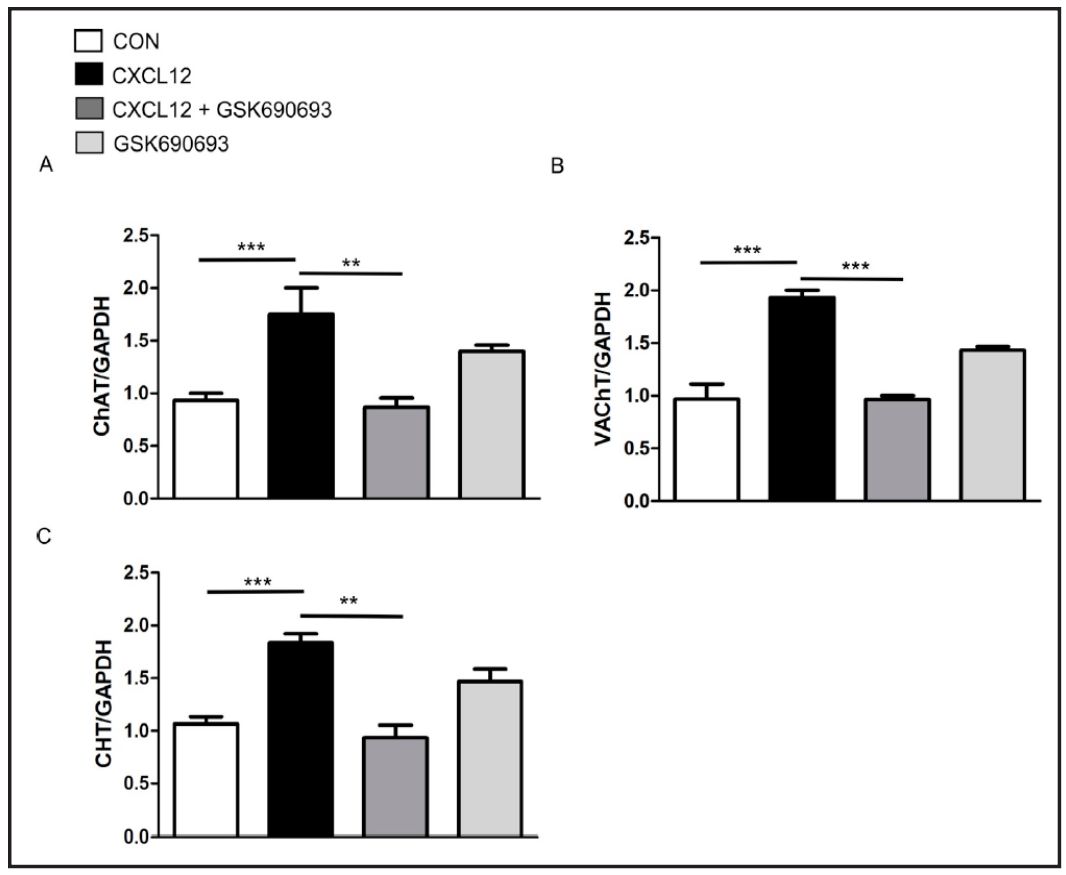
of GSK690693(1 $\mu \mathrm{M})$. C. Arithmetic means \pm SEM ( $\mathrm{n}=5$ independent experiments) of CHT1 transcriptional level in untreated(white bar) and CXCL12 treated(black bar) neurons in the presence (grey bar) of GSK690693(1 $\mu \mathrm{M}) .{ }^{* *}(\mathrm{p}<0.01),{ }^{* * *}(\mathrm{p}<0.001)$ indicates significant difference from control (ANOVA).

CXCL12-evoked cholinergic gene expression is Akt-dependent in primary septal cells

In order to conform the involvement of Akt signaling on cholinergic gene expression in primary neuronal cultures isolated from newborn SD-Rats septum(Fig. 8), after 72 h in 
culture, the cells were pre-treated with GSK690693 for $12 \mathrm{~h}$, followed by 30min CXCL12 treatment. In accordance with findings in PC12 cells, CXCL12 increased ChAT mRNA levels, an effect blunted by GSK690693(Fig. 8A). Moreover, RT-PCR revealed that both VAChT and CHT1 mRNA levels were markedly increased by CXCL12. Furthermore, pretreated with GSK69069 prevented CXCL12-induced enhancement in both CHT1 and VAChT mRNA accumulation(Fig. 8B, C).

\section{Discussion}

Our results suggest a novel potential role of Akt signaling in the regulation of cholinergic differentiation. Using PC12 cells and primary septal neurons, we demonstrated that inhibition of Akt eliminates CXCL12-dependent ChAT, VAChT as well as CHT1 mRNA expressional levels and ACh production. Moreover, ChAT and VAChT expression levels in PC12 cells are consistent with that in primary cultured septal neurons. Additionally, CHT1, another cholinergic marker co-regulated with ChAT and VAChT [31,32], is also regulated by CXCL12 in an Akt-dependent manner in septal cells.

Increasing evidence suggests that the cholinergic system and acetylcholine are important for normal cognitive function. In the central nervous system, acetylcholine and the activity of cholinergic neurons have been shown to facilitate learning and memory formation, increase alertness and attention, and signal behaviorally relevant sensory cues [33-35]. Dysfunction of the cholinergic synapse is the major cause of the Alzheimer's disease(AD)[23, 24]. Synaptic loss is the principal correlate of disease progression and loss of cholinergic neurons contributes to memory and attention deficit[36]. Furthermore, there are reports of reduced cortical ChAT activity widespread brain regions of patients with $\mathrm{AD}$ [37-39].Thus, drugs that act on the cholinergic system represent a promising option to treat AD patients.

CXCL12 is constitutively expressed in cholinergic neurons in the medial septum and substantia innominata and in dopaminergic neurons in substantia nigra pars compacta and the ventral tegmental area[8]. It is served as a modulatory neuropeptide regulating both central cholinergic and dopaminergic systems[8]. Moreover, CXCR4, a G protein-coupled receptor for the CXCL12 is also constitutively expressed in cholinergic and dopaminergic neurons $[4,17,40,41]$. CXCL12 is pointed to regulate development of the cholinergic phenotype during adult hippocampal neurogenesis and the synaptic integration of newly generated neurons. But to the best knowledge of the authors, there has been no previous report that elucidated the mechanism of which CXCL12 regulates cholinergic system until now.

PI3k/AKT pathways are required for distal axon growth and regeneration [42] and for cholinergic vesicle trafficking and migration $[43,44]$. Akt signaling pathway plays a vital role in nAChR signaling in normal lung cells and lung cancer cells[45]. But little is known about the precise mechanism by which the Akt pathway regulates cholinergic functions. Our results with Akt inhibitors indicate that at least some of the Akt effects on the cholinergic gene expression are transcriptional. Akt is involved in cell survival through interfering with the apoptosis, but also associated with the transcriptional induction of genes related to cell survival, cell cycle and metabolism $[46,47]$.

We used GSK-3 phosphorylation as an indicator of Akt activity. GSK-3 is involved in glucose metabolism, apoptosis, Wnt signaling and cancer as well as AD[48, 49]. Specifically, GSK-3 phosphorylates tau protein, hence forming neurofibrillary tangles, which is one of hallmarks of $\mathrm{AD}[50]$. Of note, the anti-apoptotic function of the PI3K/Akt/GSK-3 is pivotal for nerve survival. Furthermore, PI3K/Akt/GSK3 signaling involves regulation of the stability of $\beta$-catenin, which is necessary for acetylcholine receptor clustering at the neuromuscular junction $[51,52]$. The findings in this paper, suggesting that Akt signaling pathway is necessary for the stimulation of ACh synthesis by CXCL12/CXCR4, are in agreement with those observations. Therefore, a defect in this signaling pathway may contribute to the GSK3 


\section{Cellular Physiology Cell Physiol Biochem 2016;40:982-992 \\ \begin{tabular}{l|l|l|}
\hline DOI: 10.1159/000453155 & $\begin{array}{l}\text { C) } 2016 \text { The Author(s). Published by S. Karger AG, Basel } \\
\text { www.karger.com/cpb }\end{array}$
\end{tabular} \\ Yan et al.: CXCL12 Regulates Cholinergic Locus via Akt}

activation then form neurofibrillary tangles, and/or modify cholinergic locus, hence causing AD.

In conclusion, our results suggest that the Akt signaling pathway is necessary for the stimulation of ACh synthesis.

\section{Acknowledgements}

This study was supported by the National Natural Science Foundation of China(Grant No.81671226).

\section{Disclosure Statement}

The authors declare that they have no competing interests.

\section{References}

1 Yang F, Sun W, Yang Y, Wang Y, Li C-L, Fu H, Wang X-L, Yang F, He T, Chen J: SDF1-CXCR4 signaling contributes to persistent pain and hypersensitivity via regulating excitability of primary nociceptive neurons: involvement of ERK-dependent Nav1.8 up-regulation. J Neuroinflammation 2015;12:219.

2 Ma Q, Jones D, Borghesani PR, Segal RA, Nagasawa T, Kishimoto T, Bronson RT, Springer TA: Impaired B-lymphopoiesis, myelopoiesis, and derailed cerebellar neuron migration in CXCR4- and SDF-1-deficient mice. Proc Natl Acad Sci USA 1998;95:9448-9453.

3 Sutton A, Friand V, Brulé-Donneger S, Chaigneau T, Ziol M, Sainte-Catherine O, Poiré A, Saffar L, Kraemer M, Vassy J, Nahon P, Salzmann JL, Gattegno L, Charnaux N: Stromal cell-derived factor-1/chemokine (C-X-C motif) ligand 12 stimulates human hepatoma cell growth, migration, and invasion. Mol Cancer Res 2007;5:21-33.

4 Nagasawa T: CXCL12/SDF-1 and CXCR4. Front Immunol 2015;6:301.

5 Tang W, Wang X, Chen Y, Zhang J, Lin Z: CXCL12 and CXCR4 as predictive biomarkers of glioma recurrence pattern after total resection. Pathol Biol 2015;63:190-198.

6 Luo X, Wang X, Xia Z, Chung SK, Cheung CW: CXCL12/CXCR4 axis: an emerging neuromodulator in pathological pain. Rev Neurosci 2016;27:83-92.

$7 \quad$ Young B, Purcell C, Kuang Y-Q, Charette N, Dupré DJ: Superoxide Dismutase 1 Regulation of CXCR4Mediated Signaling in Prostate Cancer Cells is Dependent on Cellular Oxidative State. Cell Physiol Biochem 2015;37:2071-2084.

8 Banisadr G, Skrzydelski D, Kitabgi P, Rostène W, Parsadaniantz SM: Highly regionalized distribution of stromal cell-derived factor-1/CXCL12 in adult rat brain: constitutive expression in cholinergic, dopaminergic and vasopressinergic neurons. Eur J Neurosci 2003;18:1593-1606.

9 Maroun M, Richter-Levin G: Local circuit plasticity in the rat dentate gyrus: characterization and agingrelated impairment. Neuroscience 2002;112:1001-1007.

10 Ryu CH, Park SA, Kim SM, Lim JY, Jeong CH, Jun JA, Oh JH, Park SH, Oh WI, Jeun SS: Migration of human umbilical cord blood mesenchymal stem cells mediated by stromal cell-derived factor-1/CXCR4 axis via Akt, ERK, and p38 signal transduction pathways. Biochem Biophys Res Commun 2010;398:105-110.

11 Calì C, Marchaland J, Regazzi R, Bezzi P: SDF 1-alpha (CXCL12) triggers glutamate exocytosis from astrocytes on a millisecond time scale: imaging analysis at the single-vesicle level with TIRF microscopy. J Neuroimmunol 2008;198:82-91.

12 Calì C, Bezzi P: CXCR4-mediated glutamate exocytosis from astrocytes. J Neuroimmunol 2010;224:13-21.

13 Zilkha-Falb R, Kaushansky N, Kawakami N, Ben-Nun A: Post-CNS-inflammation expression of CXCL12 promotes the endogenous myelin/neuronal repair capacity following spontaneous recovery from multiple sclerosis-like disease. J Neuroinflammation 2016;13:7. 


\section{Cellular Physiology Cell Physiol Biochem 2016;40:982-992

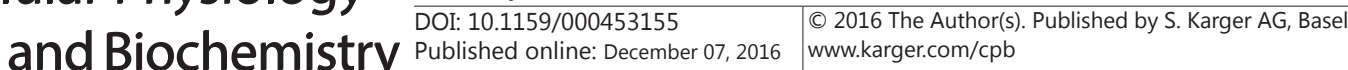 \\ Yan et al.: CXCL12 Regulates Cholinergic Locus via Akt}

14 Qin Y, Zhou Z, Zhang F, Wang Y, Shen B, Liu Y, Guo Y, Fan Y, Qiu J: Induction of Regulatory B-Cells by Mesenchymal Stem Cells is Affected by SDF-1 $\alpha$-CXCR7. Cell Physiol Biochem 2015;37:117-130.

15 Calderon TM, Eugenin EA, Lopez L, Kumar SS, Hesselgesser J, Raine CS, Berman JW: A role for CXCL12 (SDF-1alpha) in the pathogenesis of multiple sclerosis: regulation of CXCL12 expression in astrocytes by soluble myelin basic protein. J Neuroimmunol 2006;177:27-39.

16 McCandless EE, Wang Q Woerner BM, Harper JM, Klein RS: CXCL12 limits inflammation by localizing mononuclear infiltrates to the perivascular space during experimental autoimmune encephalomyelitis. J Immunol 2006;177:8053-8064.

17 Ozawa PMM, Ariza CB, Ishibashi CM, Fujita TC, Banin-Hirata BK, Oda JMM, Watanabe MA: Role of CXCL12 and CXCR4 in normal cerebellar development and medulloblastoma. Int J Cancer 2016;138:10-13.

18 18. Kucia M, Jankowski K, Reca R, Wysoczynski M, Bandura L, Allendorf DJ, Zhang J, Ratajczak J, Ratajczak MZ: CXCR4-SDF-1 signalling, locomotion, chemotaxis and adhesion. J Mol Histol 2004;35:233-245.

19 Lau JK, Brown KC, Thornhill BA, Crabtree CM, Dom AM, Witte TR, Hardman WE, McNees CA, Stover CA, Carpenter AB, Luo H, Chen YC, Shiflett BS, Dasgupta P: Inhibition of cholinergic signaling causes apoptosis in human bronchioalveolar carcinoma. Cancer Res 2013;73:1328-1339.

20 Khan MZ, Brandimarti R, Musser BJ, Resue DM, Fatatis A, Meucci O: The chemokine receptor CXCR4 regulates cell-cycle proteins in neurons. J Neurovirol 2003;9:300-314.

21 Barati MT, Lukenbill J, Wu R, Rane MJ, Klein JB: Cytoskeletal rearrangement and Src and PI-3K-dependent Akt activation control GABA(B)R-mediated chemotaxis. Cell Signal 2015;27:1178-1185.

22 Chen DY, Bambah-Mukku D, Pollonini G, Alberini CM: Glucocorticoid receptors recruit the CaMKII $\alpha$-BDNFCREB pathways to mediate memory consolidation. Nat Neurosci 2012;15:1707-1714.

23 Anderson KE: Dementia in Parkinson's Disease. Curr Treat Options Neurol 2004;6:201-207.

24 Buckingham SD, Jones AK, Brown LA, Sattelle DB: Nicotinic acetylcholine receptor signalling: roles in Alzheimer's disease and amyloid neuroprotection. Pharmacol Rev 2009;61:39-61.

25 Parsons SM: Transport mechanisms in acetylcholine and monoamine storage. FASEB J 2000;14:24232434.

26 Mattson MP, Cheng B, Davis D, Bryant K, Lieberburg I, Rydel RE: beta-Amyloid peptides destabilize calcium homeostasis and render human cortical neurons vulnerable to excitotoxicity. J Neurosci 1992;12:376-389.

27 Levy DS, Kahana JA, Kumar R: AKT inhibitor, GSK690693, induces growth inhibition and apoptosis in acute lymphoblastic leukemia cell lines. Blood 2009;113:1723-1729.

28 Feger M, Fajol A, Lebedeva A, Meissner A, Michael D, Voelkl J, Alesutan I, Schleicher E, Reichetzeder C, Hocher B, Qadri SM, Lang F: Effect of carbon monoxide donor CORM-2 on vitamin D3 metabolism. Kidney Blood Press Res 2013;37:496-505.

29 Hu Y, Qiao L, Wang S, Rong SB, Meuillet EJ, Berggren M, Gallegos A, Powis G, Kozikowski AP: 3-(Hydroxymethyl)-bearing phosphatidylinositol ether lipid analogues and carbonate surrogates block PI3-K, Akt, and cancer cell growth. J Med Chem 2000;43:3045-3051.

30 Kozikowski AP, Sun H, Brognard J, Dennis PA: Novel PI analogues selectively block activation of the prosurvival serine/threonine kinase Akt. J Am Chem Soc 2003;125:1144-1145.

31 Kobayashi Y, Okuda T, Fujioka Y, Matsumura G, Nishimura Y, Haga T: Distribution of the high-affinity choline transporter in the human and macaque monkey spinal cord. Neurosci Lett 2002;317:25-28.

32 Ferguson SM, Savchenko V, Apparsundaram S, Zwick M, Wright J, Heilman CJ, Yi H, Levey AI, Blakely RD: Vesicular localization and activity-dependent trafficking of presynaptic choline transporters. J Neurosci 2003;23:9697-9709.

33 Sarter M, Parikh V, Howe WM: Phasic acetylcholine release and the volume transmission hypothesis: time to move on. Nat Rev Neurosci 2009;10:383-390.

34 Hasselmo ME, Sarter M: Modes and models of forebrain cholinergic neuromodulation of cognition. Neuropsychopharmacology 2011;36:52-73.

35 Picciotto MR, Higley MJ, Mineur YS: Acetylcholine as a neuromodulator: cholinergic signaling shapes nervous system function and behavior. Neuron 2012;76:116-129.

36 Ferreira-Vieira TH, Guimaraes IM, Silva FR, Ribeiro FM: Alzheimer's disease: Targeting the Cholinergic System. Curr Neuropharmacol 2016;14:101-115. 


\section{Cellular Physiology Cell Physiol Biochem 2016;40:982-992 \begin{tabular}{ll|l} 
DOI: 10.1159/000453155 & $\begin{array}{l}\text { O 2016 The Author(s). Published by S. Karger AG, Basel } \\
\text { www.karger.com/cpb }\end{array}$
\end{tabular} \\ Yan et al.: CXCL12 Regulates Cholinergic Locus via Akt}

37 DeKosky ST, Harbaugh RE, Schmitt FA, Bakay RA, Chui HC, Knopman DS, Reeder TM, Shetter AG, Senter HJ, Markesbery WR: Cortical biopsy in Alzheimer's disease: diagnostic accuracy and neurochemical, neuropathological, and cognitive correlations. Intraventricular Bethanecol Study Group. Ann Neurol 1992;32:625-632.

38 Davies P: Neurotransmitter-related enzymes in senile dementia of the Alzheimer type. Brain Res 1979;171:319-327.

39 Davies P, Katzman R, Terry RD: Reduced somatostatin-like immunoreactivity in cerebral cortex from cases of Alzheimer disease and Alzheimer senile dementa. Nature 1980;288:279-280.

40 Banisadr G, Fontanges P, Haour F, Kitabgi P, Rostène W, Mélik Parsadaniantz S: Neuroanatomical distribution of CXCR4 in adult rat brain and its localization in cholinergic and dopaminergic neurons. Eur J Neurosci 2002;16:1661-1671.

41 Xu F-T, Li H-M, Yin Q-S, Liu D-L, Nan H, Zhao P-R, Liang S-W: Human breast adipose-derived stem cells transfected with the stromal cell-derived factor-1 receptor CXCR4 exhibit enhanced viability in human autologous free fat grafts. Cell Physiol Biochem 2014;34:2091-2104.

42 Kim Y, Seger R, Suresh Babu CV, Hwang S-Y, Yoo YS: A positive role of the PI3-K/Akt signaling pathway in PC12 cell differentiation. Mol Cells 2004;18:353-359.

43 Castell X, Cheviron N, Barnier J-V, Diebler M-F: Exploring the regulation of the expression of ChAT and VAChT genes in NG108-15 cells: implication of PKA and PI3K signaling pathways. Neurochem Res 2003;28:557-564.

44 Madziar B, Shah S, Brock M, Burke R, Lopez-Coviella I, Nickel A-C, Cakal E-B, Blusztajn J-K, Berse B: Nerve growth factor regulates the expression of the cholinergic locus and the high-affinity choline transporter via the Akt/PKB signaling pathway. J Neurochem 2008;107:1284-1293.

45 Singh S, Pillai S, Chellappan S: Nicotinic acetylcholine receptor signaling in tumor growth and metastasis. J Oncol 2011;2011:456743-11.

46 Brunet A, Datta SR, Greenberg ME: Transcription-dependent and -independent control of neuronal survival by the PI3K-Akt signaling pathway. Curr Opin Neurobiol 2001;11:297-305.

47 Liang J, Slingerland JM: Multiple roles of the PI3K/PKB (Akt) pathway in cell cycle progression. Cell Cycle 2003;2:339-345.

48 Asuni AA, Hooper C, Reynolds CH, Lovestone S, Anderton BH, Killick R: GSK3alpha exhibits beta-catenin and tau directed kinase activities that are modulated by Wnt. Eur J Neurosci 2006;24:3387-3392.

49 Zeng X, Tamai K, Doble B, Li S, Huang H, Habas R, Okamura H, Woodgett J, He X: A dual-kinase mechanism for Wnt co-receptor phosphorylation and activation. Nature 2005;438:873-877.

50 Takashima A, Honda T, Yasutake K, Michel G, Murayama O, Murayama M, Ishiguro K, Yamaguchi H: Activation of tau protein kinase I/glycogen synthase kinase-3beta by amyloid beta peptide (25-35) enhances phosphorylation of tau in hippocampal neurons. Neurosci Res 1998;31:317-323.

51 Zhang B, Luo S, Dong X-P, Zhang X, Liu C, Luo Z, Xiong W-C, Mei L: Beta-catenin regulates acetylcholine receptor clustering in muscle cells through interaction with rapsyn. J Neurosci 2007;27:3968-3973.

52 Wang J, Ruan N-J, Qian L, Lei W-L, Chen F, Luo Z-G: Wnt/beta-catenin signaling suppresses Rapsyn expression and inhibits acetylcholine receptor clustering at the neuromuscular junction. J Biol Chem 2008;283:21668-21675. 